\title{
Emergence of Zoonoses at Human-Animal Interface
}

\author{
Radhakrishna Sahu* , Durga Prasad Das and Subhashree Nayak \\ Fisheries and Animal Resources Development Department, Govt. of Odisha, India \\ *Corresponding author
}

\section{A B S T R A C T}

Key w o r d s
Old and new
pathogen, zoonotic
agents,
antimicrobial
resistance

Keywords

Old and new pathogen, zoonotic agents resistance

\section{Accepted:} 10 March 2020
A number of old and new pathogen has emerged or re-emerged in past 30 years. Increase in interaction at the interface of human and animals plays a crucial role in transmission of these zoonotic agents at the interface. Burgeoning human population, increased global communication, habitat destruction, bush meat consumption, intensification of animal farming. Along with emergence of antimicrobial resistance and increased incidence food borne infections are important public health implications in which human-animal interface plays a definite role. Despite initiatives taken by Indian government to consolidate inter-sectorial collaboration, still recent policies still lacks one health approach.

\section{Introduction}

Out of 1407 pathogen around $816(58 \%)$ are zoonotic in nature. While $73 \%(130 / 177)$ of emerging pathogens, are zoonotic in nature (Woolhouse and Gowtage-Sequeria, 2005). In last 30 years around 30 pathogens have emerged (Woolhouse et al., 2002; Smolinski et al., 2003)Most of the emerged pathogens are viral in nature. While RNA virus due to increased mutation rate with low proof reading in RNA viruses as compared to DNA viruses results in increased rate of emergence of RNA viruses as compared to DNA viruses Johnson et al., (2015). Emergence of disease at an interface depends on evolutionary distance between species, plasticity of pathogen to jump species barrier, and frequency of contact of susceptible species with the reservoir species (Cleaveland et al., 2007; Greger , 2007; Johnson et al., 2015). The review will focus on the factors which are contributing to emergence of zoonotic pathogens at human-animal interface.

\section{Emergence of zoonoses}

In past 30 years several zoonotic diseases viz. ebola, SARS, MERS, Nipah, Hendra, HIV, Hanta viral infection, West-nile disease, Scrub typhus, Tularemia, Lyme disease, Covid-19 have emerged or re-emerged 
(Woolhouse et al., 2002; Smolinski et al., 2003' Yee et al., 2020). As defined by WHO, an emerging zoonoses is defined as 'a zoonosis that is newly recognized or newly evolved, or that has occurred previously but shows an increase in incidence or expansion in geographical, host or vector range.' While OIE defines re-emerging zoonoses as 'an already known disease that either shifts its geographical setting or expands its host range, or significantly increases its prevalence.' Increase in interaction at human-animal interface due to increased anthropogenic intervention at the interface has resulted in increase in exposure of human to novel pathogen or existing pathogen with enhanced virulence.

\section{Emergence of zoonoses at human animal interface}

Around 6 million to 11 thousand years ago transmission of zoonotic disease at the interface began with human alteration of environment with beginning of agricultural activities. Establishment of agricultural activities might have led to increase in activities of rodents around the establishments. Around 10 thousand years ago domestication of animals began. All these alteration of human activities created a scope of increased exposure of human to animal pathogens (Dobson and Carper, 1996; Wolfe and Dunavan, 2007). It has been hypothesized that recent established human diseases at some point of time originated from animal pathogen. For example human measles originated from rinderpest like virus, smallpox virus originated from camelpox/cowpox like virus having rodent borne ancestor, and similarly pertusis virus originated from ovine or porcine source (Weiss, 2001; Gubser et al., 2004).

As identified by WHO/FAO/OIE, six major factors which are associated with emergence or re-emergence of zoonoses are habitat destruction, bushmeat consumption, intensification of animal agriculture, long distance transport of animals, live animal market, and increased demand for animal protein (WHO/FAO/OIE, 2004). Role of each factor is described in detail in the context below.

\section{Habitat destruction}

As per global forest resource assessment it has been reported that more than half of global tropical forest has been destroyed till now with an average loss of $2-3 \%$ per year (Pimm and Ayres, 2001; Patz et al., 2004) The principal reason behind habitat destruction is population blast. Current world population is estimated to be around 7.6 billion and it is expected to increase around 9.8 billion in 2050 and 11.2 billion in 2100 (UN, 2017). It has been estimated that availability of forest land per capita has decreased to 0.6 ha per person in 2015 as compared to 0.8 ha per person in 1990 . The net global forest annual loss has decreased from 7.7 million ha during 1990-2000 to 3.3 million ha during 2010-15. Although the rate of forest loss has decreased over the years, however contribution of planted forest to net global forest as compared to natural forest is gradually increasing (FRA, 2015).

Another form of habitat destruction is habitat fragmentation, which arises due to establishment of human habitation or establishment of commercial venture inside natural forest. This results in expansion of ecotone zones which helps in transmission of zoonotic agents at the interface. For example emergence of lyme disease in Connecticut, USA which was due to expansion of forests around agricultural lands thereby increased exposure to vectors and natural reservoirs of the pathogen (Goldberg et al., 2008; Laurance et al., 2013). Similarly emergence of Nipah in 
Malaysia was due to destruction of forests inhabiting bats, which subsequently fled to pig farm establishments and led to escalation of nipah outbreak in Malaysia. Migrations of bats are hypothesized to be behind emergence and re-emergence of several pathogen viz. wast nile virus, avian influenza, hendra virus disease, SARS syndrome.

\section{Bush meat consumption}

Bushmeat refers to meat derived from wild animal intended for human purpose (MilnerGulland and Bennett, 2003) Bushmeat consumption is popular in African countries, where in Congo and Amazon river basin the bush meat consumption activity is reported to be 4.5-5 million tonnes per year Fa et (2002). Hunting of wild animals poses a great risk of acquiring zoonotic pathogens as personnel involved in bush meat processing activities come in direct contact with blood and tissue of wild animals. Sick and clinically ill animals remain more susceptible to hunting. Among animal species, bats and primates pose greatest risk to human health (LeBreton et al., 2006; Subramanian, 2012; Taylor et al., 2015).

Increased bushmeat consumption is associated with increased incidence of several zoonotic diseases. Zoonotic diseases associated with consumption of bush meat species are mentioned in Table 1 Kurpiers et al., (2016). Acquired immune-deficiency syndrome, caused by HIV- 1 virus was first recognised in USA around 1981. Later the emergence was associated with increased trade activity in forest cover, which along with resulted in increased bush meat trade (Weiss and Wrangham, 1999; Larkin, 2000).

Bats due to certain important characteristics play an important role as reservoir and dissemination of zoonotic pathogen. Despite, its small size bats have a life span upto 40 years. Bats can disperse over a long range and can traverse over continents, which results in dissemination of pathogens over a wide geographical area. Bats usually roost in a large density over a small area, and due high concentration of reservoirs it facilitates random spill over of zoonotic pathogens to humans during close encounters. Bats maintain a high body temperature, which facilitates co-evolution of febrile resistant virus. Bats immune system developed in such a way that it allows multiplication of virus without development of clinical symptoms (Munshi-South and Wilkinson, 2010; Streicker et al., 2010; O'shea et al., 2014). Bats acts as common reservoir for betacoronavirus family viruses such as Covid19, SARS CoV and MERS CoV (CDC, 2020).

\section{Long distance transport of animal}

Nowadays animals are transported over a long distance due to flexibility in long distance communication. Animals are usually transported as pet animals, laboratory purpose, and food animals. Apart from that illegal smuggling of animals is one of the important reasons in dissemination of infection across continents. As per reports each year around 40,000 primates, 4 million birds, and 6,40,000 reptiles are transported for trade purpose Karesh et al., (2005). Trading of animals for food purpose has increased over five times since 1990s. Apart from these around 350 million tropical fish are traded in a year (Spellberg, 1994).

Transportation of animals over a long distance induces stress in animals which increases faecal shedding of zoonotic pathogens viz. Salmonella, Campylobacter, E. coli, and results in precipitation of latent infection Barham et al., (2002). Also stress induces susceptibility to infection. Transportation of animals increases contact 
between herds. Following introduction of reservoir animals to a new herd which are immunologically naïve to the alien pathogens often results in precipitation of outbreaks (Crews, 2004).

Transportation has played a key role in spread of several pandemics. 1998 Nipah pandemic in which more than 105 persons died (Looi, L. M., and Chua, 2007), transportation of infected pigs across Malaysia played a key role spread of Nipah across the country Presti et al., (2016). Similarly transportation of infected poultry across 8 different countries in South East Asia resulted in 2004 pandemic of H5N1 (FAO and OIE, 2007). A number of outbreaks associated transportation of animals across countries, which are mentioned in Table 2.

\section{Expansion and intensification of animal agriculture}

Since beginning of livestock revolution since, world meat, milk and egg production has increased around 4, 2.5, and 5 times respectively as compared to 1960s (FAO, 2019). Nowadays intensification of animal agriculture is gaining momentum as compared to traditional backyard rearing of animal (Thornton, 2010). In intensive farming due to presence of a large number of genotypically similar individuals at a confined place it becomes easier for a pathogen to adapt a host. In order to increase animal productivity there is selective breeding programmes are taking over a large pace. However, it results in narrowing of genetic diversity among species, which helps in easier adaptation of pathogen Drew, 2011; Behera and France, 2016; Geoghegan et al., 2016). In intensive farming there is increased human-animal contact as compared to traditional farming, facilitating transmission of zoonotic diseases at the interface (Geurden and O'Handley, 2011). Due to rapid population turnover rate, new entrants' population continuously gets admixture with existent population, which facilitates transmission of infection between herds (Brown, 2009). Due to presence of large number of animals over a small space puts the animals under stress and animals exhibit clinical signs and shed a large a large number of pathogens. Besides setting up of livestock farms in peri-urban area, acts as a focal point for transmission of zoonotic diseases in these area (Goldberg et al., 2008; Rwego et al., 2008).

\section{Live animal markets and wet markets}

Live animal markets along with wet markets can act as hotspot for transmission of zoonotic diseases and food borne pathogens. In animal markets, a diverse range of species are tied together resulting in interspecies transmission of zoonotic pathogens. Emergence of pandemics viz. H5N1, SARS, Covid-19 has been attributed to live animal markets (Sheahan et al., 2008; Okoye et al., 2013; Yee et al., 2019).

In India, meat is generally sold in wet market in open without adoption of any hygienic measures. Meat obtained from the sources is subjected to potential contamination and may result in food borne outbreaks viz. salmonellosis, staphylococcosis, campylobacteriosis (Vindigni et al., 2007).

\section{Emergence of food borne infection}

As per reports of WHO, globally around 600 million people fall ill due to food borne pathogens. Almost one in 10 persons in a year suffers from food-borne illness resulting loss of 33 million healthy life years. While average number of deaths associated with food-borne illness is around 4, 20,000 per year. Animal products remain the top contributors to these deaths. In children less than five years every one death of three death 
accounts due to food-borne illness. Norovirus, E. coli, Campylobacteria spp., No-typhoid salmonellosis alone contributes to around 550 million illnesses per year with 2, 30,000 deaths.

In South-East Asian region more than 150 million get affected with food borne illness with around 1,75,000 deaths. Children less than 5 years contribute to 60 million illness and 50,000 deaths. Novirus, non-typhoid Salmonella, and E. coli are the causative agents chiefly associated. More than half of the global deaths due to hepatitis A are from South East Asian regions (WHO, 2019).

Emerging pathogens associated with foodborne pathogens are Listeria monocytogenes, E. coli O:157 H:7, O26, O103, O111, O145, E. coli O157, Toxoplasma gondii, Giardia spp., Cryptosporidium spp., Taeniasis (Newell et al., 2010).

\section{Emergence of antimicrobial resistance}

Antibiotic is used in animal chiefly for therapeutic purpose and as growth promoter. According to estimates India produces around $2 / 3^{\text {rd }}$ of antibiotics in the world. Use of aquaculture in fish use of aquaculture in fishery industry China stands at top while India stands at $5^{\text {th }}$ position. In United States $80 \%$ use of antibiotics is targeted towards animal industry. No maximum residue limits (MRls) has been set in India for use of antibiotics in food. Although certain standards have been set in aquatic industry due to poor enforcement of regulation rampant violation of law has been observed (Van Boeckel et al., 2015; Kakkar et al., 2017; Venkatasubramanian, 2018).

As per reports of CSPI, most of the foodborne outbreaks associated with antibiotics resistant pathogens are from animal food products. Dairy products, ground beef, and poultry meat are chiefly associated with these outbreaks. Most of these outbreaks are associated with Salmonella spp. Antibiotics against which resistant is observed most commonly are tetracycline, streptomycin, ampicillin (CSPI, 2013).

In India, common antibiotic residues secreted in milk are found to be tetracycline, oxytetracycline, gentamicin, cloxacillin, and penicillin. In a study more than $40 \%$ of poultry samples obtained are resistant to more than one antibiotics. Mastitis in animals associated with drug resistant pathogens MRSA, VRSA, pathogens with resistance against antibiotics such as carbenacillin, oxacillin, imipenem, quinolone are reported from several parts of India. Besides MDR has been reported in aquaculture with resistance has been reported against antibiotics such as sulfamethoxazole, carbenacillin, oxytetracyclin, nalidixic acid, streptomycin (Kakkar et al., 2016).

These pathogens are excreted and secreted into environment and water bodies through excretions and secretions. Such antibiotic resistant pathogens enter into our food chain via consumption of meat, milk or through environmental route.

\section{India: a hotspot for zoonoses}

As per ILRI, India is one of the global hotspot for zoonotic diseases. Poverty is one of the major causes for emergence of zoonotic diseases. India remains at top in number of poor livestock keepers and global zoonoses burden. While India remains at $5^{\text {th }}$ position in endemic zoonoses prevalence. Livestock owner with literally no awareness regarding zoonotic diseases and with poor financial bearings barely adopts any biosecurity measures to prevent acquiring of zoonotic pathogens. Besides there are around 19 million stray dogs population are there in the 
country. Besides, in India meat animals are generally slaughtered in unregistered slaughter houses in an unhygienic manner and sold in wet markets (Grace et al., 2012; DAHDF, 2010). As per reports farming systems in India are chiefly based on mixed crop based livestock raising system (Fig. 1).

\section{Governmental activities in India for surveillance and control of zoonotic diseases}

A standing committee on zoonoses has been formed in 2007 ministry of health to facilitate intersectorial collaboration between veterinary and medical sector. Recently a MOU has been signed between ICMR and ICAR, for joint research on zoonotic disease, antibiotic resistance and pesticide residues (ICAR, 2016). Along with joint working group on zoonoses and food safety has also been formed to facilitate collaborative research (DHR, 2012; ICAR, 2013). Recent outbreak of avian influenza has led to establishment of Joint monitoring group on avian influenza (Ghatak and Singh, 2015). Integrated disease surveillance programme stresses upon intersectorial collaboration for better surveillance of zoonotic diseases and has recruited epidemiologists, veterinarian, microbiologists, and entomologists (NCDC, 2019).

However gaps are still observed in regard to cooperation between veterinary and medical sector at field level. Research activities targeting epidemiological factors that influence distribution of the zonotic pathogens are scarce. No separate unit for veterinary public health has been formed at centre or state government level except Goa and Manipur (Ghatak and Singh, 2015). National health policy- 2017 does not mention role of public health veterinarian in surveillance and control of zoonotic diseases (NHP, 2017). As per national strategic plan
2017-25, India aims to eliminate tuberculosis by 2025 . However it fails to mention control of tuberculosis in domestic and wild animals, birds which acts as important reservoir for MTC (Mycobacterium tuberculosis complex) and MAC (Mycobacterium avium complex) respectively (NSP 2017-25).

\section{Prevention of emergence of zoonoses}

Strengthening of human-ecosystem integrity by building national parks, protected areas with strict enforcement of rules will prevent spill over of zoonotic pathogen to domestic animals and human (Ryan and Walsh, 2011). Inclusion of molecular epidemiology in research can help to identify range of reservoirs of pathogen, its genetic variability and source of infection in an outbreak associated with zoonotic or food borne pathogen (Sonyaolu et al., 2016). Along with researches should be conducted for identification risk factors associated with presence and distribution of pathogen. Studies of these kinds will help in control of active outbreaks and prevention of future outbreaks (Liverani et al., 2013). One of the most important factors in imbalance of natural ecosystem is blast of population size. Hence controlling population growth rate can help to prevent habitat loss and can help to maintain natural integrity of ecosystem (National Research Council, 2010). An intersectorial collaboration between different sectors is crucial and strategies should be formulated with an one health approach for prevention of emergence of zoonoses (WHO, 2019).

Pasture based rearing of animals instead of intensive form of animal farming is more close to natural raising of animals. Pasture raising of animals will help to reduce stress on animals and will decrease precipitation of diseases and shedding of pathogens. Along with adoption of biosecurity practices at farms such as quarantine and isolation 
practices in farm, safe disposal of farm effluents etc should be incorporated in daily activities, which in-turn will reduce exposure of farm animals and humans to zoonotic pathogens (Sahu et al., 2018). Along with promotion of native breeds which are comparatively resistant to pathogens to that of exotic breeds, should be adopted. This will help reduce size of susceptible population (FAO, 2019). Consumption of bush meat which is on increasing trend must be discouraged to prevent transmission of pathogen associated with the activities.

For control of antibiotic resistant pathogens over use of antibiotics in animal industry must be prohibited. MRL must be set by FSSAI regarding use of antibiotics in animal food products. Strict amendment of rules must be made to ensure these standards as been met.

\section{Table.1}

\begin{tabular}{|l|l|}
\hline Species & Associated zoonotic pathogens \\
\hline Primate & $\begin{array}{l}\text { Zaire ebola virus, Tai-Forest Ebola Virus, } \\
\text { HIV-1, HTLV, Simian foamy virus, Marburg } \\
\text { virus, Strongyloides fulleborni , Entamoeba } \\
\text { histolytica, Balantidium coli, Giardia } \\
\text { intestinalis }\end{array}$ \\
\hline Rodents & $\begin{array}{l}\text { Monkey pox, Leptospira, Rabies, Mokola } \\
\text { virus, Lassa fever, Salmonella }\end{array}$ \\
\hline Ungulates & $\begin{array}{l}\text { Anthrax, Leptospirosis, Rabies, Zaire Ebola } \\
\text { Virus, Hepatitis E }\end{array}$ \\
\hline Bats & $\begin{array}{l}\text { Lagos Virus, Zaire Ebola Virus, Duvengahe } \\
\text { virus, SARS, Nipah virus disease, Hendra } \\
\text { virus disease }\end{array}$ \\
\hline
\end{tabular}

Table.2

\begin{tabular}{|l|l|l|l|}
\hline \multicolumn{1}{|c|}{ Outbreak } & Associated species & $\begin{array}{l}\text { Exporting } \\
\text { country }\end{array}$ & Reference \\
\hline Monkey pox, Texas, US & Gambian giant rat & Ghana & $\begin{array}{l}\text { Chomel et al., } \\
2007\end{array}$ \\
\hline Tularemia, West Virginia & Hare & $\begin{array}{l}\text { Central \& Eastern } \\
\text { Europe } \\
\text { China and Taiwan }\end{array}$ & $\begin{array}{l}\text { Godfroid et al., } \\
2005\end{array}$ \\
\hline $\begin{array}{l}\text { Avian Influenza, United } \\
\text { Kingdom }\end{array}$ & Finch & Middle East & $\begin{array}{l}\text { Lanciotti et al., } \\
1999\end{array}$ \\
\hline $\begin{array}{l}\text { Psittacosis, West nile } \\
\text { virus, United States }\end{array}$ & Pet birds & United States & $\begin{array}{l}\text { Holmes et al., } \\
1995\end{array}$ \\
\hline $\begin{array}{l}\text { Herpes-B virus, United } \\
\text { States }\end{array}$ & Primates & $\begin{array}{l}\text { Lynch et al., } \\
1999\end{array}$ \\
\hline \begin{tabular}{l} 
Salmonellosis, Ireland \\
\hline
\end{tabular} & Terrapins & United & \\
\hline
\end{tabular}




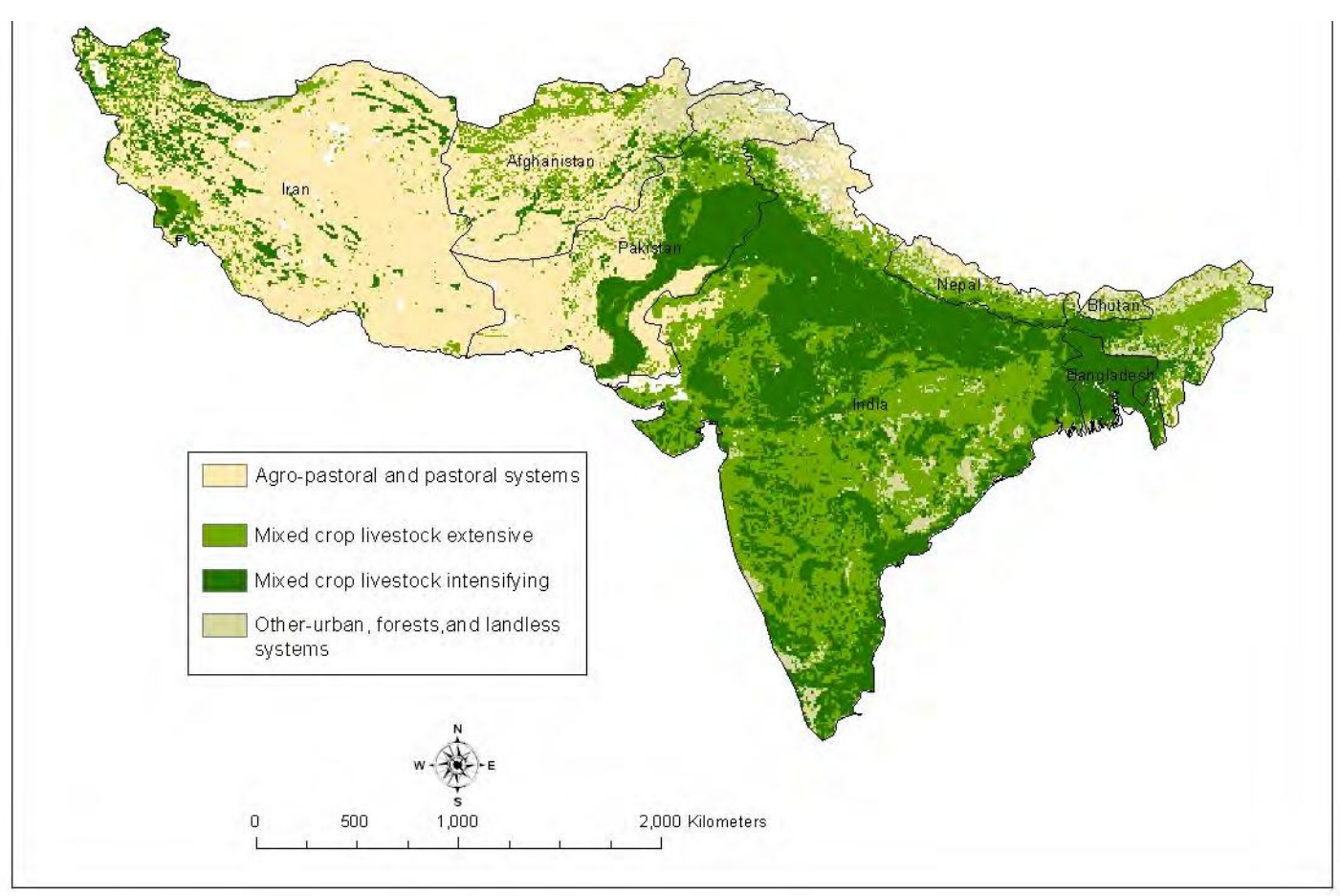

Fig.1 Livestock raising system in India Herrero et al., 2009

To control outbreaks associated with animal food steps should be taken for establishment of hygienic slaughter houses. Although prevention of Cruelty to Animals (Slaughter House) Rules, 2000 prohibits slaughter of animals anywhere except slaughter houses, this is grossly overlooked. Accreditation of slaughter house by competent organisation should be made mandatory to allow operation. Similarly, selling of meat in open wet markets should be prohibited. Sufficient measures should be adopted to prevent external contamination with chilling facility should be made available at the selling point.

Amidst increasing risk of emerging zoonotic diseases in the present situation, it is essential to adopt implement suitable strategies. Suitable policies must be formulated by government to enhance collaboration between veterinary and medical sector. Awareness should be created among farmers, regarding protection of themselves from zoonotic pathogens. Apart from that strict laws should be enforced ensure hygienic slaughter and selling of meat in local markets. Similarly emergence of AMR must be prevented by strict enforcement of law preventing indiscriminate use of antibiotic in animal sector.

\section{References}

2019 Novel Coronavirus (2019-nCoV) Situation Summary | CDC [Internet]. 2020 [Published February 2, 2020]. Available at https://www.cdc.gov/coronavirus/2019ncov/summary.html. Accessed February 9, 2020.

Barham, A. R., Barham, B. L., et al., 2002. Effect of shipping stress in beef cattle on prevalence levels of Escherichia coli O157 and Salmonella spp. from the feedyard to the packing plant. J. Food Prot, 65, 280-283.

Behera, U. K., and France, J. 2016. Integrated farming systems and the livelihood security of small and marginal farmers in India and other developing countries. 
In Advances in Agronomy (Vol. 138, pp. 235-282). Academic Press.

Brown, David (October 25, 2009). "Back where virus started, new scrutiny of pig farming". The Washington Post.

Cleaveland, S., Haydon, D. T., et al., 2007. Overviews of pathogen emergence: which pathogens emerge, when and why?. In Wildlife and emerging zoonotic diseases: the biology, circumstances and consequences of cross-species transmission (pp. 85-111). Springer, Berlin, Heidelberg.

CSPI. 2013. Centre for Science in the public interest. Antibiotic resistance in food borne pathogens. Available at: https://cspinet.org/resource/antibioticresistance-foodborne-pathogens

Department of Animal Husbandry, Dairying \& Fisheries (DAHDF), Government of India (2010). - Basic animal husbandry statistics 2010. DAHDF, New Delhi. Available at: www.dahd.nic.in/dahd/upload/BAHS_2 010.pdf.

Department of Health Research (DHR), Government of India (2012). - XII Plan Document (2012-2017). DHR, New Delhi, 342 pp. Available at: http://icmr.nic.in/Publications/plan/ ICMR\%20XIIth\%20Plan\%20(20122017).pdf.

Dobson, A. P., and Carper, E. R. 1996. Infectious diseases and human population history. Bioscience, 46(2): $115-126$.

Drew, T. W. 2011. The emergence and evolution of swine viral diseases: to what extent have husbandry systems and global trade contributed to their distribution and diversity? Revue Scientifique et Technique-OIE, 30(1): 95.

Fa, J. E., Juste, J., et al., 2002. Bushmeat consumption and preferences of two ethnic groups in Bioko Island, West
Africa. Human ecology, 30(3): 397-416.

FAO and OIE in collaboration with WHO. 2007. The Global Strategy for Prevention and Control of H5N1 Highly Pathogenic Avian Influenza

FAO. 2019. The state of agricultural biodiversity in the livestock sector. Section E. Animal genetic resources and resistance to disease. Available at: http://www.fao.org/faostat/en/\#home

FRA. 2015. Global forest resource assessment 2015. Available at: http://www.fao.org/3/a-i4808e.pdf

Geoghegan, J. L., Senior, A. M., et al., 2016. Pathogen population bottlenecks and adaptive landscapes: overcoming the barriers to disease emergence. Proceedings of the Royal Society B: Biological Sciences, 283(1837): 20160727.

Geurden, T., \& O'Handley, R. (2011). Cryptosporidiosis: An Update.

Ghatak, S., and Singh, B. 2015. Veterinary public health in India: current status and future needs. Rev. Sci. Tech. Off. Int. Epiz, 34(2).

Goldberg, T. L., Gillespie, T. R., et al., 2008. Anthropogenic disturbance promotes bacterial transmission among primates, humans, and livestock across a fragmented forest landscape. Emerg Infect Dis, 14, 1375-1382.

Grace, D., Mutua, F., et al., (2012). Mapping of poverty and likely zoonoses hotspots. Mapping of poverty and likely zoonoses hotspots. Zoonoses Project 4. Report to the UK Department for International Development. Nairobi, Kenya: ILRI

Greger, M. (2007). The human/animal interface: emergence and resurgence of zoonotic infectious diseases. Critical reviews in microbiology, 33(4), 243299.

Gubser, C., Hue, S., et al., 2004. Poxvirus genomes: a phylogenetic analysis. J Gen Vir, 85(1): 105-117. 
Herrero, M., Thornton, P.K., Notenbaert, A., Msangi, S., et al., 2009. Drivers of change in crop-livestock systems and their potential impacts on agroecosystems services and human well-being to 2030. Nairobi, Kenya: International livestock Research Institute, Nairobi.

ICAR. 2016. MoU between ICMR and ICAR. Available at: https://icar.org.in/node/4577

Indian Council of Agricultural Research (ICAR) (2013). - Expression of interest for participation in activities of the ICMR-ICAR Joint Committee for Research on Food Safety. ICAR, New Delhi. Available at: www.icar.org.in/en/node/4910.

J. Crews, 2004. Handle with care: Transporting livestock correctly pays off. Food Systems Insider, March 1. $<$ foodsystemsinsider.com/articles/ 0403/0403handle.htm>.

Johnson, C. K., Hitchens, P. L., et al., 2015. Spillover and pandemic properties of zoonotic viruses with high host plasticity. Scientific reports, 5, 14830.

Kakkar, M. 2016. Antibiotic use in small holder peri-urban dairy farms in India: sowing ignorance, reaping resistance. 4th Int. Conf. Responsible Use Antibiot. Anim. Integr. Anim. Hum. Environ. Heal. The Hague; p. 15.

Kakkar, M., Walia, K., et al., 2017. Antibiotic resistance and its containment in India. bmj, 358, j2687.

Karesh, W. B., Cook, R. A., et al., 2005. Wildlife trade and global disease emergence. Emerging infectious diseases, 11(7): 1000.

Kurpiers, L. A., Schulte-Herbrüggen, B., et al., 2016. Bushmeat and emerging infectious diseases: lessons from Africa. In Problematic Wildlife (pp. 507-551). Springer, Cham.

Larkin, J. (2000). Women, poverty and HIV infection. Canadian

Woman

Studies, 20(3).

Laurance, S. G., Jones, D., et al., 2013. Habitat fragmentation and ecological traits influence the prevalence of avian blood parasites in a tropical rainforest landscape. PLoS One, 8(10).

LeBreton, M., Prosser, A. T., et al., 2006. Patterns of bushmeat hunting and perceptions of disease risk among central African communities. Animal Conservation, 9(4), 357-363.

Liverani, M., Waage, J., et al., 2013. Understanding and managing zoonotic risk in the new livestock industries. Environmental Health Perspectives, 121(8), 873-877.

Lo Presti, A., Cella, E., et al., 2016. Origin and evolution of Nipah virus. Journal of Medical Virology, 88(3), 380-388.

Looi, L. M., and Chua, K. B. 2007. Lessons from the Nipah virus outbreak in Malaysia. Malaysian Journal of Pathology, 29(2), 63-67.

Milner-Gulland, E. J., and Bennett, E. L. 2003. Wild meat: the bigger picture. Trends in Ecology \& Evolution, 18(7): 351-357.

Munshi-South, J., and Wilkinson, G. S. 2010. Bats and birds: exceptional longevity despite high metabolic rates. Ageing research reviews, 9(1), 12-19.

National health policy (NHP) 2017. Available at:

http://cdsco.nic.in/writereaddata/nationa 1-health-policy.pdf

National Research Council, 2010. Sustaining global surveillance and response to emerging zoonotic diseases. 3. Drivers of Zoonotic Diseases National Academies Press.

NATIONAL STRATEGIC PLAN FOR TUBERCULOSIS ELIMINATION (NSP) 2017-2025. Available at: https://tbcindia.gov.in/WriteReadData/ NSP\%20Draft\%2020.02.2017\%201.pdf 
NCDC. 2019. Integrated disease surveillance programme. Available at: https://ncdc.gov.in/index 1.php?lang=1\& level $=1 \&$ sublinkid $=143 \&$ lid $=54$

Newell, D. G., Koopmans, M., et al., 2010. Food-borne diseases - the challenges of 20 years ago still persist while new ones continue to emerge. International journal of food microbiology, 139, S3S15.

O'shea, T. J., Cryan, P. M., et al., 2014. Bat flight and zoonotic viruses. Emerging infectious diseases, 20(5), 741.

Okoye, J., Eze, D., et al., 2013. Serologic evidence of avian influenza virus infections among Nigerian agricultural workers. Journal of medical virology, 85(4): 670-676.

Patz, J. A., Daszak, P., et al., 2004. Unhealthy landscapes: policy recommendations on land use change and infectious disease emergence. Environmental health perspectives, 112(10), 1092-1098.

Pimm, S. L., Ayres, M., et al., 2001.. Can we defy nature's end?

Rwego, I. B., ISABIRYE- BASUTA, G. I. L. B. E. R. T., et al., 2008. Gastrointestinal bacterial transmission among humans, mountain gorillas, and livestock in Bwindi Impenetrable National Park, Uganda. Conservation Biology, 22(6), 1600-1607.

Ryan, S. J., and Walsh, P. D. 2011. Consequences of non-intervention for infectious disease in African great apes. PloS one, 6(12).

Sahu, R., Kale, S. B., et al., 2018. Apparent prevalence and risk factors associated with occurrence of Coxiella burnetii infection in goats and humans in Chhattisgarh and Odisha, India. Comparative immunology, microbiology and infectious diseases, 60, 46-51.

Sanyaolu, A., Okorie, C., Mehraban, et al., 2016. Epidemiology of Zoonotic
Diseases in the United States: a comprehensive review. J. Infect. Dis. Epidemiol, 2, 021.

Sheahan, T., Rockx, B., et al., 2008. Pathways of cross-species transmission of synthetically reconstructed zoonotic severe acute respiratory syndrome coronavirus. Journal virology, 82(17): 8721-8732.

Smolinski, M. S., and Hamburg, M. A. et al., 2003. Pathogen Discovery, Detection, and Diagnostics. In Microbial Threats to Health: Emergence, Detection, and Response. National Academies Press (US).

Spellberg, I. F. (1994). Evaluation and assessment for conservation: ecological guidelines for determining priorities for nature conservation (Vol. 4). Springer Science \& Business Media.

Streicker, D. G., Turmelle, A. S., et al., 2010. Host phylogeny constrains cross-species emergence and establishment of rabies virus in bats. Science, 329(5992), 676679.

Subramanian, M. 2012. Zoonotic disease risk and the bushmeat trade: assessing awareness among hunters and traders in Sierra Leone. EcoHealth, 9(4): 471-482.

Taylor, G., Scharlemann, J. P. W., et al., 2015. Synthesising bushmeat research effort in West and Central Africa: a new regional database. Biological Conservation, 181, 199-205.

Thornton, P. K. 2010. Livestock production: recent trends, future prospects. Philosophical Transactions of the Royal Society B: Biological Sciences, 365(1554): 2853-2867.

UN (United nations). 2017. World population projected to reach 9.8 billion in 2050 , and 11.2 billion in 2100. Available at:https://www.un.org/development/des a/en/news/population/world-populationprospects-2017.html

Van Boeckel, T. P., Brower, C., et al., 2015. 
Global trends in antimicrobial use in food animals. Proceedings of the National Academy Sciences, 112(18), 5649-5654.

Venkatasubramanian, K.V., 2018. India leads increasing antibiotic consumption. Chemical \& Engineering News, Vol.96, No.16, 15-15

Vindigni, S. M., Srijan, A., et al., 2007. Prevalence of foodborne microorganisms in retail foods in Thailand. Foodborne Pathogens and Disease, 4(2), 208-215.

Weiss, R. A. 2001. Animal origins of human infectious disease. Phil. Trans. R. Soc. Lond. B, 356, 957-977.

Weiss, R. A., and Wrangham, R. W. 1999. From Pan to pandemic. Nature, 397(6718), 385-386.

WHO. 2019. Infographics: Estimates of the global burden of foodborne diseases. https://www.who.int/foodsafety/areas_ work/foodbornediseases/ferg_infographics/en/

WHO. 2019. Managing public health risks at the human-Animal-environment interface. Available at: https://www.who.int/zoonoses/en/

WHO/FAO/OIE 2004. Report of the WHO/FAO/OIE joint consultation on emerging zoonotic diseases.

Wolfe, N. D., Dunavan, C. P., et al., 2007. Origins of major human infectious diseases. Nature, 447(7142): 279-283.

Woolhouse, M. E., and Gowtage-Sequeria, S. 2005. Host range and emerging and reemerging pathogens. Emerg. Infect. Dis., 11(12): 1842.

Woolhouse, M. E., Webster, J. P., et al., 2002. Biological and biomedical implications of the co-evolution of pathogens and their hosts. Nature genetics, 32(4): 569577.

Yee, J., Unger, L., et al., (2020). Novel coronavirus 2019 (COVID- 19): Emergence and implications for emergency care. Journal of the American College of Emergency Physicians Open.

\section{How to cite this article:}

Radhakrishna Sahu, Durga Prasad Das and Subhashree Nayak. 2020. Emergence of Zoonoses at Human-Animal Interface. Int.J.Curr.Microbiol.App.Sci. 9(03): 2894-2905. doi: https://doi.org/10.20546/ijcmas.2020.903.333 